\title{
Dyeing of Wool Fabrics with Extracted Eco-Friendly Natural Dyes from Rhus Parviflora (Tung) Using Chemical Mordants: Comparison of Fastness Properties and Colour Strength with Some Mordants
}

\author{
SHYAM VIR SINGH ${ }^{1 *}$ and M. C. PUROHIT ${ }^{2}$ \\ ${ }^{1}$ Department of Chemistry, SGRR (PG) College, Pathribag, Dehradun, Uttarakhand, India \\ ${ }^{2}$ Department of Chemistry, HNB Garhwal University, Campus Pauri, \\ Pauri Garhwal, Uttarakhand, India \\ shyamveer91084@rediffmail.com
}

Received 28 July 2013 / Accepted 30 August 2013

\begin{abstract}
Soaked wool fabrics were dyed with natural dyes extracted from the leaves of Rhus parviflora. The colour fastness properties and colour strength of dyed wool fabrics were determined and compared. From the comparative study of fastness properties and colour strength of the dyed wool samples, Rhus parviflora in simultaneous mordanting method with $3 \%$ mordant combination gives better results as compared to the natural dye samples without mordants as blank.
\end{abstract}

Keywords: Rhus parviflora, Wool fabrics, Fastness, Mordants, Natural dye

\section{Introduction}

Anciently, the purpose of colouring textile was initiated using colours of natural source, until synthetic colours/dyes were invented and commercialized. Almost all the synthetic colourants being synthesized from petrochemical sources through hazardous chemical processes posses threat towards its eco-friendliness. Upto the end of $19^{\text {th }}$ century natural dyes were the main colourants for textiles. Recently, interest in the use of natural dyes has been growing rapidly due to the result of stringent environmental standards imposed by many countries in response to toxic and allergic reactions associated with synthetic dyes ${ }^{1}$. In 1856, William Perkins accidently synthesized a basic dye, with the advent of synthetic dyes, the use of natural dyes declined tremendously because the existing natural dyes failed to full fill the demand of the market. The widely and commercially used synthetic dyes impart strong colors but causes carcinogenicity and inhibition of benthic photosynthesis ${ }^{2}$. The District Chamoli, Uttarkashi and Pithoragarh of Uttarakhand traditional wool and woolen products and they were still used for dyeing by natural dyes. Certain problems with the use of natural dyes in textile dyeing are colour yield, complexibility of dyeing process, reproducibility results, limited shades, blending problems and inadequate fastness properties ${ }^{3,4}$. 
Mordants are metal salts which produce an affinity between the fabric and the dye $\mathrm{e}^{5,6}$. Alum, chrome, stannous chloride, copper sulphate, ferrous sulphate etc. are the commonly used mordants ${ }^{7}$. Rhus parviflora species is very rare to give natural dyes properties and this species give us good fastness grades with respect to grey scale. Isolation of natural dyes from these species could not be done till now because recent data of the literature did not show these results of natural dyes properties in the past. The present study has been undertaken so as to revive the age-old are of dyeing with natural dyes. It has been recently reported that yellow coloured component (Figure 1) was found in the leaves of Rhus parviflora, which could be possible dyes candidate for wool fabrics. Colour fastness is the resistance of a material to change any of its colour characteristics or extent of transfer of its colorants to adjacent white materials in touch. The natural dyes present in plants and animals are pigmentary molecules ${ }^{8}$ which impart colour to the materials. There are several plants that provide natural dyes which are used in the textile industry. However, the common drawbacks of natural dyes are their nonreproducible and nonuniform shades, poor to moderate colour fastness and lack of scientific information on the chemistry of dyeing and standardized dyeing methods ${ }^{9}$. Many reports are available on application of natural dyes on cotton/wool ${ }^{10-12}$. The present investigation deals with the aqueous extraction of natural dyes from the leaves of Rhus parviflora grow in almost all cold and dense parts of Garhwal Himalaya in Uttarakhand, India. The aim of present work has been carried out to prepare eco-friendly natural dyes the leaves of Rhus parviflora and then apply them on wool fabrics. In the present work an attempt has been made to study the effect of mordanting and dyeing properties of wool fabrics such as, washing, rubbing, light fastness and perspiration ${ }^{13}$ and also to visualize the effect of metallic mordants have been undertaken.<smiles>O=c1c(O)c(-c2ccc(O)c(O)c2)oc2cc(O)cc(O)c12</smiles>

(Quercetin)

Figure 1. Chemical structure of yellow colour component from leaves of Rhus parviflora

\section{Experimental}

Soaked plain weave woolen fabrics were purchased from the market of Gopeshwar, Uttarakhand, which were used for the study. Analytical reagents (AR) grade ferrous sulphate, aluminium sulphate, potassium dichromate, stannous chloride, commercial grade acetic acid, common salt, sodium carbonate were used. Depending upon the mordant used, the colour obtained on textiles from the leaves of Rhus parviflora extract may give different shades.

\section{Methods}

\section{Extraction of colour component}

For optimizing the extraction method the aqueous extraction of dye liquor was carried out under varying conditions, such as time of extraction, temperature of extraction bath and material-to-liquor ratio. In each case, the optical density or absorbance value at a particular maximum absorbance wavelength $\left(\lambda_{420 \mathrm{~nm}}\right)$ for the ethanol extract of plant parts were estimated by using Hitachi-U-2000 UV-VIS absorbance spectrometer. 


\section{Dyeing of wool fabrics with the extract of leaves of Rhus parviflora}

The wetted out wool samples were entered into dye baths containing required amount of dye extract and water. After 15 minutes, required amount of sodium carbonate and sodium chloride were added. The dyeing was carried out for one hour at $60^{\circ} \mathrm{C}$. The dyed samples were dried in air without washing to make them ready for pre, simultaneous and postmordanting using metallic salts.

\section{Pre-mordanting of wool fabrics with metallic salts}

Soaked wool fabric with or without pre-mordanting were further mordanted prior to dyeing using $1-3 \%$ of any one of the chemical mordants, such as aluminium sulphate, potassium dichromate, stannous chloride and ferrous sulphate, at $60{ }^{\circ} \mathrm{C}$ for 30 minutes with materialto-liquor ratio of 1:20. The samples treated with metal salts were dyed with the dye extract.

\section{Simultaneous mordanting of wool fabrics with metallic salts}

Soaked wool fabrics were treated with both dye extract and metal salts simultaneously, using $1-3 \%$ of any one of the chemical mordants, such as aluminium sulphate, potassium dichromate, stannous chloride and ferrous sulphate, at $60{ }^{\circ} \mathrm{C}$ for 30 minutes with materialto-liquor ratio of 1:20.

\section{Post-mordanting of wool fabrics with metallic salts}

Soaked wool fabrics were dyed with dye extract. The wetted out wool samples were entered into different dye baths containing required amount of dye extract and water. After $15 \mathrm{~min}$ required amount of sodium sulphate was added. After 30 minutes required amount of sodium chloride was added. The dyeing was carried out for one hour at $60{ }^{\circ} \mathrm{C}$. The dyed samples were taken out, squeezed and used for treatment with metal salts process without washing. The dyed cotton samples were treated with different metal salts using $1-3 \%$ of any one of the chemical mordants, such as aluminium sulphate, potassium dichromate, stannous chloride and ferrous sulphate, at $60{ }^{\circ} \mathrm{C}$ for 30 minutes with material-to-liquor ratio of 1:20. In all the above three methods, after the dyeing is over, the dyed samples were repeatedly washed with water and then dried in air. Finally, the dyed samples were subjected to soaping with $2 \mathrm{gpL}$ soap solution at $50{ }^{\circ} \mathrm{C}$ for 10 minutes, followed by repeated water wash and drying under sun.

\section{Measurements}

\section{Determination of surface colour strength (K/S value)}

The K/S value of the undyed and dyed wool fabrics was determined by measuring surface reflectance of the samples using a computer-aided Macbeth 2020 plus reflectance spectrophotometer, using the following Kubelka-Munk equation with the help of relevant software:

$$
\mathrm{K} / \mathrm{S}=\left(1-\mathrm{R}_{\lambda \max }\right)^{2} / 2 \mathrm{R}_{\lambda \max }
$$

Where $\mathrm{K}$ is the coefficient of absorption; $\mathrm{S}$ is the coefficient of scattering and $\mathrm{R}_{\lambda \max }$ is the surface reflectance value of the sample at a particular wavelength, where maximum absorption occurs for a particular dye/colour component.

\section{Evaluation of colour fastness}

Colour fastness to washing of the dyed fabric samples was determined as per IS: 764-1984 method using a Sasmira launder-O-meter following Is-3 wash fastness method. The wash 
fastness rating was assessed using grey scale as per ISO-05-A02 (loss of shade depth) and ISO-105-AO3 (extent of staining) and the same was cross-checked by measuring the loss of depth of colour and staining using Macbeth 2020 plus computer-aided colour measurement system attached with relevant software. Colour fastness to rubbing (dry and wet) was assessed as per IS: 766-1984 method using a manually operated crock meter and grey scale as per ISO-105-AO3 (extent of staining) and the test samples were graded for change in colour and staining using grey scales.

\section{Results and Discussion}

The colour strength values of wool fabrics dyed with the leaves of Rhus parviflora obtained in this study by using single mordanting method are presented and compared in Tables 1, 2 and 3 . From the results, it was observed that among the one plant part, Rhus parviflora showed better colour strength values. In all the three dyeing methods, simultaneous method gave excellent results. In all the three methods of dyeing, using one plant part, the mordants ferrous sulphate and aluminium suphate show excellent colour strength values. For dyeing of wool, 1\%, 2\% and $3 \%$ mordant concentrations were used for the present study and by which $\mathrm{K} / \mathrm{S}$ values were observed with the different mordanting methods and mordants with respect to plant which is mentioned as tabular picture as an under the respective Tables. Among these three concentrations 3\% mordant concentration gave better results. The colour fastness values of wool fabrics dyed with leaves of Rhus parviflora obtained in this study by using single mordanting method are presented and compared in Table 4. From the results, it was observed that among the two plant parts, Rhus parviflora showed better light fastness properties. Similar rub fastness and perspiration fastness values were obtained. Rhus parviflora showed better wash fastness with dyed wool fabrics. In all the three dyeing methods, simultaneous method gave excellent results. In all the three methods of dyeing, using one plant part, the mordants ferrous sulphate and aluminium suphate show excellent results. Among the three concentrations 3\% mordant concentration gave better fastness results. A better light fastness (GS: 4-5) was noted in the present study when compared to that of reports (LF: 2) when ferrous sulphate and aluminium sulphate were separately mordanted in pre mordanting method. The analysis of colour strength in Tables 1, 2 and 3 indicate that aluminium sulphate mordanted dyes woolen samples shows better colour strength than mordanted by ferrous sulphate and when separately mordanted in pre mordanting method ${ }^{14}$ showed better colour strength as compared to the colour strength value observed in the present study. A better wash fastness (GS: 4-5) was observed in the present study ${ }^{15}$ as compare to when ferrous sulphate was used as a mordant in pre-mordanting method (GS: 4). Similar results for rub and perspiration fastness were obtained in the previous works reported ${ }^{16-18}$ as mentioned in below Table 4 and Table 5 reveals about the dyed woolen samples with and without synthetic mordants used.

Table 1. Surface colour strength of Rhus parviflora (RP) dyed wool fabric by using $1 \%$ mordant concentration. K/S value without mordant: wool- 1.51(RP)

\begin{tabular}{cccc}
\hline \multirow{2}{*}{$\begin{array}{c}\text { Mordant } \\
\text { concentration:1\% }\end{array}$} & $\begin{array}{c}\text { Kre- } / \mathrm{S}(\lambda=420 \mathrm{~nm}) \\
\text { mordanting }\end{array}$ & $\begin{array}{c}\text { Simultaneous } \\
\text { mordanting }\end{array}$ & $\begin{array}{c}\text { Post } \\
\text { mordanting }\end{array}$ \\
\cline { 2 - 4 } & $\mathrm{RP}$ & $\mathrm{RP}$ & $\mathrm{RP}$ \\
\hline Aluminium sulphate & 1.80 & 2.90 & 2.77 \\
Potassium dichromate & 1.21 & 1.28 & 1.35 \\
Ferrous sulphate & 1.75 & 2.65 & 2.55 \\
Stannous chloride & 1.65 & 2.58 & 2.42 \\
\hline
\end{tabular}


Table 2. Surface colour strength of Rhus parviflora (RP) dyed wool fabric by using $2 \%$ mordant concentration. $\mathrm{K} / \mathrm{S}$ value without mordant: wool- 1.51(RP)

\begin{tabular}{cccc}
\hline \multirow{2}{*}{$\begin{array}{c}\text { Mordant } \\
\text { concentration: 2\% }\end{array}$} & \multicolumn{3}{c}{$\mathrm{K} / \mathrm{S}(\lambda=420 \mathrm{~nm})$} \\
\cline { 2 - 4 } & Pre-mordanting & Simultaneous mordanting & Post mordanting \\
\hline Aluminium sulphate & $\mathrm{RP}$ & $\mathrm{RP}$ & $\mathrm{RP}$ \\
Potassium dichromate & 1.90 & 2.75 & 2.69 \\
Ferrous sulphate & 1.27 & 1.34 & 1.40 \\
Stannous chloride & 1.72 & 2.65 & 2.60 \\
\hline
\end{tabular}

Table 3. Surface colour strength of Rhus parviflora (RP) dyed wool fabric by using $3 \%$ mordant concentration. $\mathrm{K} / \mathrm{S}$ value without mordant: wool- 1.51(RP)

\begin{tabular}{cccc}
\hline \multirow{2}{*}{$\begin{array}{c}\text { Mordant } \\
\text { concentration: 3\% }\end{array}$} & \multicolumn{3}{c}{$\mathrm{K} / \mathrm{S}(\lambda=420 \mathrm{~nm})$} \\
\cline { 2 - 4 } & Pre-mordanting & Simultaneous mordanting & Post mordanting \\
\hline Aluminium sulphate & 1.95 & $\mathrm{RP}$ & $\mathrm{RP}$ \\
Potassium dichromate & 1.34 & 2.90 & 2.87 \\
Ferrous sulphate & 1.86 & 1.43 & 1.40 \\
Stannous chloride & 1.76 & 2.70 & 2.65 \\
\hline
\end{tabular}

Table 4. Comparison of fastness properties and colour strength of dyed wool fabrics using single mordants WF-Wash fastness, LF-Light fastness, PF-Perspiration fastness, RF-Rub fastness, GS-Grayscale, PM-Pre mordanting and SM-Simultaneous mordanting

\begin{tabular}{|c|c|c|c|c|c|c|c|c|c|}
\hline \multirow{3}{*}{$\begin{array}{l}\text { Plant parts } \\
\text { used } \\
\text { for dyeing }\end{array}$} & \multirow{3}{*}{ Mordant used } & \multicolumn{7}{|c|}{ Fastness Properties } & \multirow{3}{*}{ References } \\
\hline & & \multirow[t]{2}{*}{ Method } & \multirow{2}{*}{\multicolumn{2}{|c|}{$\mathrm{LF}$}} & \multicolumn{2}{|c|}{ RF } & \multicolumn{2}{|c|}{ PF } & \\
\hline & & & & & Dry & Wet & Acidic & Alkaline & \\
\hline \multirow{4}{*}{$\begin{array}{l}\text { Leaves of } \\
\text { Rhus } \\
\text { parviflora }\end{array}$} & Ferrous sulphate, & SM & 5 & 4 & 4 & 5 & 4 & 4 & \multirow{4}{*}{ Present study } \\
\hline & $3 \%$ & PM & 4 & 4 & 5 & 5 & 5 & 4 & \\
\hline & Aluminium & SM & 4 & 5 & 5 & 5 & 5 & 5 & \\
\hline & sulphate (3\%) & PM & $4-5$ & $4-5$ & 4 & 5 & 5 & 5 & \\
\hline \multirow{2}{*}{$\begin{array}{l}\text { Onosma } \\
\text { echioides }\end{array}$} & $\begin{array}{c}\text { Ferrous sulphate } \\
(3 \%)\end{array}$ & SM & 5 & 2 & 5 & 5 & 4 & 5 & \multirow{2}{*}[16]{} \\
\hline & $\begin{array}{l}\text { Aluminium } \\
\text { sulphate }(5 \%)\end{array}$ & SM & 5 & 2 & 4 & $3-4$ & 5 & 5 & \\
\hline $\begin{array}{l}\text { Fountain } \\
\text { flower }\end{array}$ & $\begin{array}{c}\text { Ferrous sulphate } \\
\qquad(3 \%)\end{array}$ & SM & $4-5$ & 5 & $4-5$ & 4 & $4-5$ & $4-5$ & {$[18]$} \\
\hline \multirow{2}{*}{$\begin{array}{l}\text { Mangifera } \\
\text { indica }\end{array}$} & $\begin{array}{c}\text { Ferrous sulphate } \\
(2.5 \%)\end{array}$ & SM & 5 & 4 & $4-5$ & 4 & 5 & 5 & \multirow{2}{*}[16]{} \\
\hline & $\begin{array}{c}\text { Aluminium } \\
\text { sulphate }(12.5 \%)\end{array}$ & SM & 5 & 4 & $4-5$ & 4 & 5 & 5 & \\
\hline \multirow{2}{*}{$\begin{array}{l}\text { Colquhouni } \\
\text { a coccinea }\end{array}$} & $\begin{array}{l}\text { Ferrous sulphate } \\
(2.5 \%)\end{array}$ & PM & $4-5$ & $4-5$ & 5 & 5 & 5 & 5 & \multirow{2}{*}{ [14] } \\
\hline & $\begin{array}{c}\text { Aluminium } \\
\text { sulphate }(12.5 \%)\end{array}$ & PM & 4 & 4 & 4 & 4 & 4 & 4 & \\
\hline \multirow{2}{*}{$\begin{array}{l}\text { Pongamia } \\
\text { pinnata }\end{array}$} & $\begin{array}{c}\text { Ferrous sulphate } \\
(2.5 \%)\end{array}$ & SM & - & 5 & $4-5$ & $4-5$ & - & - & \multirow[b]{2}{*}[17]{} \\
\hline & $\begin{array}{c}\text { Aluminium } \\
\text { sulphate }(12.5 \%)\end{array}$ & SM & - & 5 & $4-5$ & $4-5$ & - & - & \\
\hline $\begin{array}{l}\text { Neem tree } \\
\text { bark }\end{array}$ & $\begin{array}{c}\text { Aluminium } \\
\text { sulphate }(12.5 \%)\end{array}$ & PM & 3 & $2-3$ & $4-5$ & $4-5$ & - & - & {$[15]$} \\
\hline
\end{tabular}


Table 5. Pictures of dyed samples with and without synthetic mordants

\begin{tabular}{|c|c|c|c|}
\hline $\begin{array}{l}\text { Dye Bearing Plant } \\
\text { (As taken under } \\
\text { study) } \\
\end{array}$ & $\begin{array}{c}\text { Used } \\
\text { Mordanting } \\
\text { Methods } \\
\end{array}$ & $\begin{array}{c}\text { Dyeing Without } \\
\text { Mordant } \\
\text { ( Taken as Reference) }\end{array}$ & $\begin{array}{l}\text { Dyeing With different } \\
\text { Synthetic Mordants }\end{array}$ \\
\hline & $\begin{array}{c}\text { Pre } \\
\text { Mordanting }\end{array}$ & & \\
\hline & $\begin{array}{c}\text { Simultaneous } \\
\text { Mordanting }\end{array}$ & & \\
\hline Rhus parviflora & $\begin{array}{c}\text { Post } \\
\text { Mordanting }\end{array}$ & & \\
\hline
\end{tabular}

\section{Conclusion}

From the comparative study of fastness properties and colour strength of the dyed woolen samples, Rhus parviflora in simultaneous mordanting method with $3 \%$ mordant combination gives better results as compared to the Blank dye samples as revealing by the data and the scope of this study give us much more help to textile industries and rural areas to use this plant for application of natural dyes rather than synthetic dyes on fabrics and find out good results of fastness grades of textiles on a large scale.

\section{References}

1. Anitha K and Prasad S N, Current Science, 2007, 92(12), 1681-1682.

2. Adeel S, Ali S, Bhatti I A and Zsila F, Asian J Chem., 2009, 21(5), 3493-3499.

3. Sachan K and Kapoor V P, Ind J Tradit Knowl., 2007, 6(2), 270-278.

4. $\quad$ Siva R, Current Science, 2007, 92(7), 916-919.

5. Vankar P S, Shankar R and Wijayapala S, Journal of Textile and Apparel, Technology and Management, 2009, 6(1), 1-11.

6. $\quad$ Samanta A K and Agarwal P, Indian J Fib Text Res., 2009, 34, 384-399.

7. Mahangade R R, Varadarajan P V, Verma J K and Bosco H, Ind J Fib Tex Res., 2009, 34, 279-282.

8. Bain S, Singh O P and Kang K, Man-made Textiles in India, 2002, 45(8), 315. 
9. Gulrajani M L, Gupta D and Gupta P, Indian Journal of Fibre and Textile Research, 2003, 28(4), 466-470.

10. Anderson B, Creative Spinning, Weaving and Plant Dyeing, Angus and Robinson, Singapore, 1971, 24-28.

11. Kumaresan M and Palanisamy P N, Int J Appl Eng Res., 2010, 5(12), 2031-2037.

12. Kumaresan M, Palanisamy P N and Kumar P E, Int J Chem Res., 2011, 2(1), 11-14.

13. Goodarzian H and Ekrami E, W, Appl Sci J., 2010, 8(11), 1387-1389.

14. Vankar P S, Shankar R and Mahanta D, Asian Dyer, 2010, 51-54.

15. Boonroeng $\mathrm{S}$, Boonkerdrum $\mathrm{P}$, Chadee and Sangkumpra R, International Conference on the role of Universities in Handon Education, Rajamangala University of Technology, Lanna, Chiang-Mai, Thailand, 2009, 1.

16. Bains S, Singh O P, Goraya G and Kang M, J Tex Associ., 2003, 64(1), 23-26.

17. Kumaresan M, Palanisamy P N and Kumar P E, Nature Environment and Pollution Technology, 2010, 9(3), 547-552.

18. Mahale G, Bhavani K, Sunanda R K and Sakshi M, Man-made Textiles in India, 1999, 42(11), 453.

19. Bain S, Singh O P and Kang K, Man-made Textiles in India, 2002, 45(8), 315.

20. Gulrajani M L, Gupta D and Gupta P, Indian Journal of Fibre and Textile Research, 2003, 28(4), 466-470. 